\title{
Human Rights Half Measures: Avoiding Accountability in Post-War Sri Lanka
}

\section{INTRODUCTION}

Insincere human rights behavior is a common feature of the international system. Although there is an increasingly detailed system of obligations, enforcement is imperfect, creating opportunities to evade the rules. States sign onto treaties with which they never intend to comply, knowing that they are unlikely to suffer penalties. They participate in institutions whose dictates they plan to ignore. ${ }^{1}$ These dynamics have led many to conclude that human rights commitments are simply "cheap talk". ${ }^{2}$ But such "talk" is not always cheap. States routinely engage in human rights behavior that incurs significant costs but doesn't meet their obligations. Some of these actions might be explained as inadequate good faith efforts, ${ }^{3}$ but often they are undertaken by states with clear preferences not to comply.

For example, facing massive international outcry after security forces killed more than 150 civilians at an opposition rally in 2009 , Guinea's ruling junta created a commission of inquiry to investigate. The body comprised 31 commissioners, including four foreign judges who had to be flown in to take part, as well as a team of police investigators. The move was extremely unpopular with the security sector, who feared taking the blame for the massacre. Yet even as it incurred the risk of a coup by creating the commission, a move that might suggest a genuine commitment to improving human rights, or at least to selling international audiences on its sincerity, the regime continued to recruit militias and openly build up repressive capacity. Likewise, in response to international condemnation of its violent repression of Arab Spring demonstrations, Bahrain created

\footnotetext{
${ }^{1}$ Hathaway 2002; Hathaway 2007; Neumayer 2005; Hafner-Burton 2013.

2 Krasner 1999; Goldsmith \& Posner 2002; Hafner-Burton \& Tsutsui 2005.

3 Chayes \& Chayes 1995.
} 
three institutions with a mission to end custodial torture: an ombudsman's office, a special investigations unit, and a prisoners and detainees rights commission. Despite the millions of dollars spent on these institutions, the government simultaneously enacted harsher laws to punish dissent and continued to use disproportionate force against protesters. ${ }^{4}$

In both cases, international rights groups dismissed these efforts as "window-dressing" that failed in their ostensible missions. ${ }^{5}$ Guinea's commission of inquiry exonerated the regime while significantly undercounting the stadium massacre's death toll. Bahrain's new institutions did not meaningfully improve its record on torture. In both cases, these measures failed to prevent ongoing international pressure. Bahrain faced escalating censure from human rights NGOs, Western governments, and the UN in the months and years following the creation of its anti-torture bodies. And Guinea was subjected first to a UN Secretary General-empaneled commission of inquiry, and then to an International Criminal Court investigation.

These are examples of states that undertook expensive and/or politically inconvenient action in response to international human rights pressure, but nevertheless remained non-compliant with their obligations to (either) prevent and punish torture or provide accountability for mass atrocities. Why pay the costs to create institutions that don't satisfy those demanding action? Are states that do this simply miscalculating how these measures will be received, or is there a more sophisticated logic to this behavior?

In this article, I advance a theory to explain this phenomenon, which I call "human rights half measures". While prior work has examined states' incentives to engage in incomplete compliance with human rights obligations, these studies have typically assumed an intent either of

\footnotetext{
4 AI 2015.

${ }^{5}$ Reuters 2015; HRW 2015.
} 
complying or of appeasing norm-promoting members of the international community. ${ }^{6}$ But the sole audience for many states engaging in half measures is not, as prior literature on insincere behavior has assumed, the Western governments and international NGOs that promote and monitor human rights.

Those engaged in policing human rights must convince others to support them. And it is these others — states that are less informed, less engaged, and may have domestic incentives against robust human rights action—who make up a potentially receptive audience for half measures. These "swing" states can either support or block multilateral action on human rights. I therefore argue that repressive states that are reluctant to comply with their human rights obligations will employ half measures as a strategy to prevent the mobilization of cohesive international pressure and censure. In essence, this is a coalition-blocking effort, aimed at securing swing states' support and insulating these supporters from the reputational consequences of supporting a human rights violator.

I illustrate these dynamics with a case study of response to international demands for justice in Sri Lanka, where the government refused to investigate allegations of mass atrocities but nevertheless created a series of weak accountability institutions. I demonstrate that although Sri Lanka strongly preferred not to pursue accountability, it paid significant resource costs and risked angering its domestic political support base to respond to international pressure. I show that the repeated creation of non-compliant institutions, while prompted by demands from Western governments, the United Nations, and international NGOs, played better to a different audience: developing states on the United Nations Human Rights Council who had reason to be hesitant about human rights interference in sovereign affairs.

\footnotetext{
${ }^{6}$ Chayes \& Chayes 1995; Risse, Ropp, \& Sikkink 1999; Franklin 2008; Lebovic \& Voeten 2009; Hawkins \& Jacoby 2010 ; Krain 2012; Murdie \& Davis 2012; Hillebrecht 2014.
} 
This article's core contributions are its introduction of an overlooked audience for human rights behavior, "swing" states who can either support or block multilateral action, and its suggestion that hypocritical behavior can protect the audience's reputation, as well as the hypocritical actor's. My argument that repressive states pursue half measures in part to give these swing states cover to side with them against human rights promotors engages and contributes to literatures on compliance with international law, the efficacy of human rights pressure, and the role of rhetoric in international politics. While this article focuses on the specific context of human rights, the theory developed here has widespread application to other issue areas in which enforcement of international rules is uncertain and relies on multilateral action. By theorizing the role of a swing state audience in influencing both violator state behavior and international response, I offer a new account of the politics of pressure and hypocrisy in international relations.

\section{THEORY}

Traditional theories of compliance treat the question of state response to international law as a binary, comprising rule-induced compliance and intentional non-compliance. Pushback to this dichotomy has complicated the category of compliance by treating the concept as a scale encompassing high and low values, ${ }^{7}$ and by including additional categories such as coincidental or bad faith compliance. ${ }^{8}$

Aside from the recognition of the possibility of good-faith efforts that fall short of meeting international standards, ${ }^{9}$ noncompliance has received less attention in typologies of rule-motivated behavior. Instead, scholarship on noncompliance has focused on why states make insincere

\footnotetext{
7 Morrow 2007; Hillebrecht 2009.

${ }^{8}$ Downs, Rocke, \& Barsoom 1996; Mitchell 2007, Buzas 2016.

${ }^{9}$ Chayes \& Chayes 1995.
} 
commitments in the first place. Prominent accounts suggest that states may be attempting to placate a domestic audience, but intend to revert to the status quo once pressure has dissipated $;^{10}$ that the rewards for joining a treaty regime from the international community, so-called "signing benefits", may be too good to pass up; ${ }^{11}$ or that states may not expect to have to follow through or to face penalties for noncompliance. ${ }^{12}$

A related literature looks at whether and how international pressure affects the behavior of repressive states, and yields very mixed findings. ${ }^{13}$ While some studies have found modest effects of increased pressure on human rights violators, ${ }^{14}$ others have shown that the conditions under which these effects occur are tightly constrained by politics. ${ }^{15}$ And where pressure does trigger improvements on specific rights, they may be offset by worsening performance on others. ${ }^{16} \mathrm{~A}$ number of studies suggest, however, that insincere commitments can lead states to deliver more on human rights and pay greater costs than they would like, by empowering domestic constituencies or providing leverage to external audiences. ${ }^{17}$

The most prominent argument in this vein, Risse and Sikkink's "Spiral Model", 18 suggests that insincere commitments undertaken to deflect international pressure can lead repressive states all the way to full compliance. In response to naming and shaming, states that are vulnerable to external

\footnotetext{
${ }^{10}$ Cardenas 2007; Vreeland 2008.

${ }^{11}$ Hathaway 2002.

12 Hafner-Burton \& Tsutsui 2005; Landsman 2005; Hathaway 2007.

13 Hafner-Burton \& Ron 2009.

14 Ramos, Ron, \& Thoms 2007; Murdie \& Davis 2011; Krain 2012.

15 Cardenas 2007; Franklin 2008.

16 Hafner-Burton 2008.

17 Hafner-Burton \& Tsutsui 2005; Dai 2005; Smith-Cannoy 2012.

18 Risse, Ropp, \& Sikkink 1999.
} 
pressure may make "tactical concessions", which can take the form of rhetoric, treaty ratification, or even enactment of domestic policies. Although these measures are undertaken disingenuously, over time they become habitual, contributing to the internalization and institutionalization of human rights norms. The result is that even seemingly "inconsequential policy actions" can "end up entrapping repressive governments" into compliance. ${ }^{19}$

These existing accounts of state behavior in the presence of international rules and pressure offer little traction on repressive states' decisions to undertake expensive, political inconvenient, but noncompliant, action on human rights. Existing typologies of compliance omit noncompliant behavior aside from inaction and inadequate good-faith attempts. Theories of insincere commitments cannot fully account for behavior that is costly in both resource and political terms. And finally, accounts like the Spiral Model, that explain how repressive states responding to pressure might find themselves on a slippery slope from cheap talk to costly compliance, offer limited insight into decisions to undertake half measures. Unlike the set of cases in which the Spiral Model has been theorized to operate, states employing this strategy are choosing up front to engage in costly, but noncompliant, action.

Recent scholarship on state behavior in the presence of rules and pressure recognizes that the strategies repressive states use to push back against their human rights commitments "extend well beyond just noncompliance", ${ }^{20}$ and introduces models of backlash ${ }^{21}$ and evasion. ${ }^{22}$ The account I offer here, of the deployment of half measures to provide an audience of swing states with a justification for defying human rights promoters, fits into this growing literature on resistance to the

\footnotetext{
${ }^{19}$ Simmons 2013.

${ }^{20}$ Cooley \& Schaaf 2017.

21 Vinjamuri 2017.

22 Buzas 2016.
} 
international human rights project. It also engages the literature on rhetorical entrapment by theorizing the role of "framing competitions" in producing international human rights outcomes. ${ }^{23}$ Finally, it proposes a novel role for hypocrisy in international relations: rather than just protecting the hypocritical actor's reputation, hypocrisy lets the audience escape the reputational consequences of supporting an obvious human rights violator.

The logic underlying this strategy requires some teasing out. It rests on the fact that enforcement of international human rights is irregular. Policing of compliance with obligations is piecemeal, formalized through the monitoring and adjudication arrangements of individual treaties, and often depends upon fellow members of a treaty pursuing enforcement. In the human rights arena, their motivation to do so is limited. Unlike the case of a trade treaty, signatories to a human rights convention aren't injured by another party's noncompliance and so have no obvious incentives to police each other's performance. International oversight bodies and NGOs substitute for some of the task of monitoring members' compliance, but they (generally) cannot penalize infractions. Their role is to document and publicize abuses, in the hopes that states will punish their peers for noncompliance. But there's no immediate reciprocal mechanism through which states can do this. Instead, they face an array of options ranging from public condemnations, to reducing aid or trade, to sponsoring a U.N. resolution, to military intervention.

All of these options incur costs. States are therefore less likely to engage strongly on others' human rights malfeasance in the absence of a compelling reason to do so: a historical association with the target state, a relationship to the victim group, or a strong commitment to and bureaucratic apparatus for promoting human rights abroad. Even where one or more of these motivators exist, it may be trumped by political exigencies. And because punishing human rights deficits often presages

\footnotetext{
${ }^{23}$ Krebs \& Jackson 2007.
} 
a role in remedying them, even strongly engaged states prefer to act multilaterally. This preference opens up opportunities for strategic behavior on the part of violator states.

Consider a simplified scenario:

In a crackdown following an alleged coup attempt, a repressive regime detains 2,000 suspected plotters and dissidents without trial. Six months later, some have been permitted sporadic visits from their families, but the fates of others are unknown. None have been granted their right to counsel, and there are credible reports of widespread torture during interrogations in the immediate aftermath of the attempt. The violator state is a signatory to the International Convention on Civil and Political Rights (ICCPR) and is in direct contravention of its obligations thereto. Several Western states have raised this issue in their officials' public statements and indicated they will introduce the matter at the next U.N. Human Rights Council meeting.

The violator state, which strongly prefers to keep the alleged coup plotters in detention where they can't threaten the regime's hold on power, and fears that transparency about the crackdown could cause widespread unrest, now has three options: It can continue to do nothing. It can attempt to satisfy the activist states' demands that it meet its ICCPR obligations. Orit can try to convince the other voting members of the Human Rights Council to side with it against the activist states calling for action.

While satisfying the activist states' demands would likely involve the release of detainees and the provision of restitution for those killed or tortured in custody, and/or filing charges and proceeding to speedy trial of alleged coup plotters, the violator state might reasonably expect that taking the third option would require it to do considerably less. — Perhaps filing charges against a handful of high-profile detainees, and a promise to review the cases of the others over a threemonth period. These measures would still carry resource costs and political risks, but to a lesser 
extent than full compliance. And they might be enough to convince an audience of swing states, with their own reasons to be cautious about muscular human rights enforcement, that they will not suffer reputational damage if they resist the activists' states calls for an international condemnation or inquiry.

Faced with activist states identifying human rights abuses and strong domestic political incentives not to rectify them, violator states have good reason to gamble on a middle path between doing nothing and full compliance. As the stylized example above indicates, the success of this strategy doesn't rely on convincing the activist states. It can succeed by swaying another audience: the states these activist states must convince to join in for multilateral action. In effect, this is coalition-blocking behavior.

The example above discusses potential action by the U.N. Human Rights Council, because its institutional profile makes it the logical (and most common) site of lobbying for multilateral human rights engagement. But the theoretical insights it generates are more broadly applicable, even outside of the institutions (like the Human Rights Council or the Security Council) that formally require multilateral action. Human rights promoting states must convince others to go along with their enforcement efforts if they don't want to bear the costs alone. Targeting these others, who may be less informed, less engaged, or less willing to support robust human rights enforcement, can be a successful strategy to buy a violator state a reprieve from international human rights pressure.

Critically, the success of a half measures strategy does not require that violator states convince this third-party audience of the rightness of their actions. Following the literature on rhetorical entrapment's insight that "persuasion does not exhaust the ways through which rhetoric 
might shape political contest", ${ }^{24}$ I argue that violator states can recruit peer states' support by framing their conflict with human rights promoting actors in a way that is consistent with those peer states' existing normative commitments. ${ }^{25}$ In a setting like the Human Rights Council, where action requires a coalition of willing participants and no state has a veto, framing controversies over how states' human rights behavior should be characterized are particularly high stakes. Successful half measures strategies are likely to tap into existing framing controversies in human rights fora (i.e. disputes about rights as a universal vs. Western imperialist project). I therefore expect violator states pursuing a half measures strategy to deploy rhetoric emphasizing themes like sovereignty and Global South solidarity, rather than the human rights norm-focused arguments they might use if their primary goal were to convince human rights promoting actors in the West that their behavior is compliant with their obligations.

The half measures logic introduced here is distinct from, but not incompatible with, the mechanisms of miscalculation and habituation underlying the Spiral Model in three key regards. First, and most importantly, half measures are not undertaken with the expectation of satisfying domestic or international human rights promotors. Second, half measures are the result of an affirmative choice to engage in costly human rights behavior, not an inadvertent consequence of cheap talk that becomes binding. And third, half measures are unlikely to constitute the first step on a slippery slope to compliance envisioned in the Spiral Model's account of tactical concessions.

States undertake half measures in response to international pressure when full compliance is politically untenable domestically. In these contexts, the path to compliance is not slippery; it is obstructed. The "best case scenario" is therefore that half measures operate as a sort of one-way

\footnotetext{
${ }^{24}$ Krebs \& Jackson 2007. See also Schimmelfennig 2001.

25 Petrova 2016.
} 
ratchet, establishing a new floor for the state's performance on the human rights obligation in question. While Risse and Sikkink suggest that the pull towards compliance is strongest when tactical concessions are accompanied by broader trends of liberalization that accelerate and entrench processes of human rights norm habituation and internalization, the theoretical logic advanced here predicts that full compliance following from half measures is not just less likely, but impossible, in the absence of significant political change.

The logic presented here also differs fundamentally from existing theories in its account of the role of hypocrisy. Hypocrisy, the practice of "proclaiming adherence to rules while busily violating them", ${ }^{26}$ is common in the international system, where rules are often honored in the breach. ${ }^{27}$ It can "undermine[ ] trust and credible commitments" and trigger backlash against norms. ${ }^{28}$ However, some scholars suggest that it may also act as a "civilizing force"; ${ }^{29}$ actors are refraining from violations of norms, even if they are doing so disingenuously. The "slipperiness" of the slope in the Spiral Model relies on the fact that disingenuous behavior can become habitual and internalized over time, and that hypocrisy can therefore be a force for positive change. But by contrast with tactical concessions, which tend to be accompanied by norm-reinforcing rhetoric, one of the hallmarks of a half measures approach is explicit resistance to demands for full compliance. While inadvertent habituation and norm internalization is plausible following half-hearted tactical concessions, it is far less likely when the actor has undertaken half measures while violently protesting international human rights pressure.

\footnotetext{
26 Finnemore 2011.

27 Krasner 1999.

28 Finnemore 2011; Lynch 2008.

${ }^{29}$ Elster 1997.
} 
Existing accounts of hypocrisy in international relations identify hypocrites' motivation as the desire not to be seen to be a bad actor or suffer the reputational consequences. Although some studies note that the audiences for hypocritical action may have incentives to collude in hypocrisy to avoid the costs of challenging it,$^{30}$ the impetus is still the protection of the hypocritical actor's reputation. By contrast, I suggest that repressive states deploy human rights half measures in a strategy calculated less to protect their own reputation than their audience's. This is not to say that they don't also seek to preserve their own reputation, however, they are acting to prevent a significantly worse outcome than reputational loss.

States that choose a half measures strategy are doing so because domestic politics prevents them from undertaking a response to pressure that would approximate compliance closely enough to preserve their reputation as a human rights abiding actor. Their primary motivation is therefore to avoid more stringent penalties (for instance, sanctions or an international inquiry) by blocking the formation of a coalition that would support punitive action. Of course, they would prefer to convince those putting pressure on them that they are compliant and thereby avoid reputational damage as well, but they know that half-measures that significantly under-shoot the mark are unlikely to be successful in this goal. Half measures are therefore best understood not as a serious attempt at convincingly feigning compliance, but as a convenient fiction, intended to give a sympathetic audience cover to avoid appearing to be protecting a human rights violator.

There are several empirical implications of the theory presented here. We should expect to see states engaging in half measures when they face serious potential consequences for failing to meet their human rights obligations but have strong domestic political incentives not to comply. This behavior will be distinguishable from "cheap talk" because it will incur significant resource

\footnotetext{
30 Lynch 2008.
} 
and/or political costs. It will also be distinct from the creation of institutions that are non-compliant with international norms, but responsive to domestic pressure, because it will go against observable domestic preferences. Finally, it will be distinguishable from inadequate good faith efforts to comply because it will be accompanied by clear efforts to resist human rights pressure. Most critically, half measures should be accompanied by clear signaling to swing state audiences in the form of sovereignty rhetoric, invocations of developing world solidarity, and emphasis on resisting Western conceptions of human rights.

\section{METHODS}

Because the theory presented here involves explicit claims about causal processes, a process tracing approach is best suited to assessing its explanatory value. ${ }^{31}$ Although process tracing of a single case study cannot establish the general explanatory power of a theory, it allows for an assessment of its strength relative to alternate explanations. ${ }^{32}$ It is particularly valuable when the relationship between cause and outcome is reasonably well-established, but the precise mechanisms underlying the effect are unclear. ${ }^{33}$ Tracing these links between possible causes and observed outcomes requires fine-grained descriptive data. ${ }^{34}$

I use a detailed case study of debates about accountability in post-war Sri Lanka to explore the causal logic of human rights half measures. Sri Lanka is well suited to test these arguments because it has faced strong international pressure to provide accountability for mass atrocities and strong domestic political incentives in favor of impunity. It is in exactly the position in which we

\footnotetext{
${ }^{31}$ Mahoney 2010.

32 George and Bennett 2005.

33 Gerring 2007.

${ }^{34}$ Bennett 2010; Collier 2011.
} 
would expect a state to engage in half measures. The case is also significant for human rights theory and practice. More than 40,000 civilians are believed to have been killed by government forces in the final days of Sri Lanka's civil war. Countless others were tortured, raped, and disappeared. This is a mass atrocity that ranks behind only Syria, Darfur, and Myanmar as some of the worst governmentled violence against civilians in the $21^{\text {st }}$ century. Yet because Sri Lanka is not a member of the International Criminal Court, and has been protected from U.N. Security Council action by China, pursuing justice for these abuses requires costly coordination among international actors. And as Gary Bass has shown, international security imperatives can be a powerful driver of impunity for mass atrocities. ${ }^{35}$ Post-war Sri Lanka is therefore an excellent exemplar of how efforts to enforce human rights play out in hard cases.

The fact that international debates over post-war justice in Sri Lanka played out primarily in the U.N. Human Rights Council adds to the value of the case. Because of the Human Rights Council's role as a "chamber of peer review" "36, it is the venue in which human rights perpetrators most frequently engage in efforts to defend their behavior to an audience of fellow states. It is therefore a likely site for observing the sorts of framing contests the theory anticipates. And as scholars of the Human Rights Council (and its predecessor organization, the U.N. Commission for Human Rights) have observed, "the plurality of weak states and their ability to employ organizational leverage to their advantage” means that outcomes antithetical to powerful states’ preferences are highly possible and indeed common. ${ }^{37}$ This is valuable because it establishes that a real benefit is available to perpetrator states that win the framing contest; there is clear precedent for

\footnotetext{
35 Bass 2016

36 Annan 2005.

${ }^{37}$ Lebovic \& Voeten 2006.
} 
coalitions of "weak" states to defeat powerful human rights promoters. Finally, in addition to the Human Rights Council being an important institution to study in its own right, its politics may prospectively offer a more generally applicable model of multi-polar human rights enforcement in an age of U.S. retreat on rights.

I constructed the case study through several years of qualitative research. The sensitive nature of the subject matter - unacknowledged mass atrocities - called for a deeply embedded approach to build trust with key informants and develop the contextual knowledge necessary to assess and interpret contradictory claims about profoundly politicized events. As other scholars have observed, such an approach has "a marked advantage over work based solely on formal interviews" when researching sensitive subjects. ${ }^{38}$ It allows the researcher to analyze the "meta-data" of an interview_- 'informants' spoken and unspoken thoughts and feelings which they do not always articulate in their stories or interview responses, but which emerge in other ways". ${ }^{39}$ This is particularly important in repressive environments like post-war Sri Lanka where silences on sensitive topics can convey as much information as what is said. The ability to understand such silences, both externally enforced and self-imposed, is critical to analyzing the fraught politics of these contexts. The findings presented below therefore draw on a combination of interviews, participant observation, field observation, and primary source research undertaken over the course of six trips to Sri Lanka. ${ }^{40}$

This fieldwork presented some challenges. On my first visit to Sri Lanka, the phrase "war crimes" was rarely heard in public. Discussions about post-conflict justice were conducted in

\footnotetext{
38 Parkinson 2013.

${ }^{39}$ Fujii 2010.

40 This fieldwork was conducted in July-August 2013, October-November 2013, February-March 2014, January 2015, July-August 2016, and July 2017.
} 
whispers with eyes peeled for listeners. Activists and members of civil society who advocated for accountability were labeled traitors and threatened with violence. International organizations and foreign governments that raised the issue of abuses by the military were derided as terroristsympathizers. Meanwhile, the government engaged in extensive monitoring and surveillance (both electronic and physical) of individuals critical of the regime.

Despite the precautions required by these dynamics, I was able to travel all over the country, including to seven of the eight districts in the former war zone, and speak with people from all walks of life about justice for war crimes. In total, I have conducted more than 75 formal interviews on the domestic politics of accountability with involved individuals ranging from members of the victim community, to domestic human rights activists, to former Sri Lankan military leaders, to representatives of international civil society. ${ }^{41} \mathrm{I}$ conducted additional interviews about the international politics of accountability in New York, Washington D.C., London, Geneva, and Chennai, as well as hundreds of hours of off-the-record conversations and participant observation at meetings on Sri Lanka at the U.S. State Department and the U.K. Parliament, at the $25^{\text {th }}$ Session of the U.N. Human Rights Council in March 2014, and at conferences, meetings, and social events with activists in Sri Lanka and abroad. ${ }^{42}$ In combination, these methods yielded detailed and comprehensive data about five years of back-and-forth between Sri Lanka and the international community on the issue of post-war justice.

\footnotetext{
${ }^{41}$ Most of these interviews are cited on first reference with a brief description of the interviewee, location, and date, and on any following references simply with the description of the interviewee. Where there were heightened concerns about an individual's safety, or where s/he requested additional confidentiality measures for another reason, I have used modified citation formats that omit some or all of this information.

42 There are numerous citations to both Sri Lankan and international media below. In many instances, I use these to provide a publically available source to confirm information I received off the record. All such citations have been triangulated from multiple sources.
} 


\section{EVIDENCE FROM SRI LANKA}

In the aftermath of Sri Lanka's decades-long civil war, evidence emerged that the security forces had committed war crimes and crimes against humanity on a massive scale. Ten years later, approximately 150,000 people remain unaccounted for. But despite increasingly insistent calls for accountability from survivors and members of the international community, for years the Sri Lankan government flatly refused to investigate or prosecute the authors of these atrocities.

Nevertheless, during its seven-year tenure in power after winning the war, the administration of President Mahinda Rajapaksa created a spate of human rights institutions at moments of acute international pressure. All had mandates tangentially related to accountability, but none were actually tasked with investigating alleged violations of the laws of war. These institutions met with criticism from the government's staunchly nationalistic domestic constituency, and skepticism from those calling for justice. Sri Lanka's actions therefore exemplify the puzzle outlined above: Why take this costly and inconvenient action if it doesn't secure the benefits of compliance? Below, I review the allegations of war crimes and calls for accountability before documenting the "half measures" that Sri Lanka took in response to international pressure. I then present evidence that a primary audience for these measures was non-activist U.N. Human Rights Council members.

\section{A. Allegations of War Crimes \\ i. THE END OF THE LONG WAR}

Sri Lanka's fight against the Liberation Tigers of Tamil Eelam (LTTE) came to a bloody end in May 2009. State-perpetrated abuses of human rights had been common throughout the decadeslong conflict, but civilian loss of life escalated shockingly in the final days. As government forces advanced across the Vanni region of northern Sri Lanka, the 330,000 civilians living under LTTE control were caught between them and their target. Repeatedly displaced as the army pushed 
forward, the panicked civilians ended up trapped on a narrow stretch of land between the Bay of Bengal and the Nanthikadal Lagoon. The war's final battle took place there, near the village of Mullivaikkal. In the days leading up to it, an estimated 40,000 civilians lost their lives, many to government shelling of hospitals and so-called "No Fire Zones". ${ }^{43}$

The LTTE was utterly defeated. Thousands of fighters had been killed in the final phase of the war, and thousands more taken into government custody. Some of these prisoners of war would be tortured, raped, or summarily executed, their brutal fates recorded in grainy cell phone videos taken by the giddy victorious army. Others landed in "rehabilitation" camps. Many never made it home to their families. The civilians who emerged from Mullivaikkal were also detained, impounded in a vast network of IDP camps where conditions were grim and abuses rampant. Meanwhile, the Sri Lankan government declared its "humanitarian operation" a success and prepared to celebrate "Victory Day", a newly-declared public holiday.

For Sinhalese citizens in southern Sri Lanka, a nightmare had ended. The ever-present fear of a suicide attack finally lifted. Many in the south had never met any Tamils, believed the LTTE to be monsters, and felt only relief that the leaders of the rebellion had been slaughtered en masse. They did not doubt the government's assurances that the final push had been conducted with the utmost care for civilian safety. They had no desire to question the official story.

\section{ii. Rumors of a Bloodbath}

As the war ground to a close, journalists and aid workers had no access to the battlefield. ${ }^{44}$ However, doctors operating inside the siege area were able to radio information out regarding

\footnotetext{
43 Darusman et al. 2011.

${ }^{44}$ Cronin-Furman 2017.
} 
casualty numbers. Together with testimony from escaping civilians and the eyewitness account of a U.N. official, these numbers painted a picture of indiscriminate bombardment of civilian populations as well as targeting of hospitals and No Fire Zones.

As information about the dire plight of civilians began to emerge, Sri Lanka vehemently denied the reports. At a special session of the U.N. Human Rights Council, Western governments called for an international inquiry into abuses committed by both sides. But on May 27, 2009, the Rajapaksa regime scored a diplomatic victory. It pushed through the Human Rights Council a resolution welcoming "the liberation by the Government of Sri Lanka of tens of thousands of its citizens that were kept by the Liberation Tigers of Tamil Eelam against their will as hostages". ${ }^{45}$ No mention was made of violations of international law or the need for accountability.

\section{iii. Relations With the West Start to Go SOUTH}

If a majority of Human Rights Council members was willing to accept Sri Lanka's portrayal of the brutal last days of the war as a hostage rescue, many Western governments were not. Intransigence over human rights issues in the aftermath of the war profoundly affected Sri Lanka's relationships with the West. Bilateral relations with the U.S., traditionally warm, had begun to decline in 2007 when Congress reduced economic assistance and suspended military aid and arms sales to Sri Lanka over concerns about human rights violations by the security forces. In 2010, Congress halted all non-humanitarian aid following a screening on Capitol Hill of the Channel 4 documentary “Sri Lanka’s Killing Fields", which showed clear evidence of war crimes. In 2013, humanitarian assistance was reduced from an $\$ 8$ million allocation to $\$ 6$ million. ${ }^{46}$

\footnotetext{
45 UNHRC 2009.

46 United States Department of State 2013.
} 
Sri Lanka's relationship with other major aid donors suffered similarly. In 2010 the E.U. suspended the GSP+ trade benefit and many European countries curtailed their bilateral development aid. Over the 2009-2012 period, disbursements from "traditional development partners" (the U.S., Japan, and Europe, along with the international development banks) decreased from $48.76 \%$ to $29.30 \%$ of foreign development finance. ${ }^{47}$

These penalties failed to induce the Sri Lankan government to change course. And international actors pursuing justice for war crimes had limited options in the face of this refusal to act. Because Sri Lanka is not a member of the International Criminal Court, there was no automatic international mechanism available to investigate the alleged atrocities. An international inquiry would instead require multilateral action, either through (1) a U.N. Security Council referral of the situation to the International Criminal Court; (2) the establishment of a specialized tribunal by the Security Council; or (3) the creation of an international investigation by either the Security Council or the Human Rights Council. Sri Lanka’s close relationship with China, which strengthened as Western governments withdrew preferential trade and aid over human rights concerns, prevented action at the Security Council. That left the Human Rights Council as the primary site of contestation over accountability.

\section{B. Half Measures}

\section{i. Dueling Reports}

When the U.S. State Department released a report detailing extensive violations of international law during the final phase of the war, ${ }^{48}$ Sri Lanka rejected the findings as an attempt "to bring the government of Sri Lanka into disrepute, through fabricated allegations and concocted

\footnotetext{
${ }^{47}$ International Alert 2013.

48 U.S. Department of State 2009.
} 
stories". ${ }^{49}$ It addressed the report with a two-pronged line of argument that would become a persistent refrain: First, "the Sri Lanka Armed Forces were scrupulous in affording protection to the civilians and safeguarding their welfare"; and second, "Sri Lankas [sic] domestic jurisprudence provides all the necessary scope for those perceiving themselves subjected to a violation of their human rights". 50

Yet Sri Lanka took no action as the evidence mounted. When a year had passed with no sign of a domestic response, United Nations Secretary-General Ban yielded to Western pressure and created a "Panel of Experts on Accountability in Sri Lanka." This body would ultimately conclude that the final push to defeat the LTTE was a "grave assault on the entire regime of international law" and call for a full international investigation. ${ }^{51}$ But from the beginning, Sri Lanka resisted its work, calling it "an unwarranted and unnecessary interference with a sovereign nation". ${ }^{2}$

At the same time, Sri Lanka created its own mechanism: The Lessons Learnt and Reconciliation Commission (LLRC). The move was surprising, given the regime's furious insistence that Sri Lanka had no human rights issues in need of investigation. What's more, it faced allegations from political opponents that it was caving to international pressure. ${ }^{53}$ But, as the director of one Colombo civil society organization explained, the government "could see the signs of the U.N. mobilizing" and "fear[ed] a war crimes tribunal". ${ }^{44}$

\footnotetext{
49 Nasaw 2009.

50 Ministry of Foreign Affairs 2009.

51 U.N. Panel of Experts 2010.

${ }^{52}$ Ministry of External Affairs 2010.

53 See section V.A. below.

${ }^{54}$ Colombo Civil Society Member Interview (I). 2013. Colombo, August 5.
} 
It quickly became clear that the LLRC would not deliver anything like justice. As an individual involved in the LLRC's work pointed out, it role was "not projected as an accountability mechanism as such" but rather "to promote reconciliation" ${ }^{55}$ The mandate was to investigate the failure of the 2002 ceasefire and to make recommendations to avoid a recurrence of communitarian violence. This, the government apparently felt, came close enough to dealing with alleged to war crimes "to be a counterpoise to international action". ${ }^{56}$ Members of the activist community spoke harshly of the LLRC's mandate, characterizing it as window-dressing on the government's refusal to investigate the alleged atrocities. As one victims' advocate put it: "Their task was to sweep it under the carpet." 57

Many members of both domestic and international civil society declined to participate in the LLRC's work out of concerns about its “inadequate mandate, insufficient guarantees of independence, and lack of witness protection". ${ }^{58}$ Nevertheless, the members of the LLRC spent 18 months taking testimony from thousands of Sri Lankans. Apparently, they were shocked by what victims and witnesses told them. A member of the LLRC staff confided that the testimony was "very, very difficult to hear". 59

In late 2011, the LLRC released its report, including a comprehensive treatment of interethnic relations that members of Colombo civil society pronounced themselves "pleasantly surprised" by. ${ }^{60}$ Among its recommendations, the LLRC called for the establishment of a database

\footnotetext{
55 Confidential Interview.

${ }^{56}$ Colombo Civil Society Member Interview (I).

${ }^{57}$ Human Rights Activist Interview.

58 AI 2011.

${ }^{59}$ Confidential Interview.

${ }^{60}$ Colombo Civil Society Member Interview (VI). 2013. Colombo, August 14.
} 
of those detained by the government along with other measures aimed at "bringing a sense of closure" ${ }^{61}$ But its members resisted the conclusion that the stories they had heard were the result of the security forces' intentional actions. The LLRC's most publicized finding was that the Sri Lankan military "had not deliberately targeted civilians in the $\mathrm{N}[\mathrm{o}] \mathrm{F}[\mathrm{ire}] \mathrm{Z}[\mathrm{one}] \mathrm{s}$ ". ${ }^{62}$ In other words, it avoided the issue of accountability for atrocities entirely.

\section{ii. The ARmy COURT OF INQUiRY}

As the March 2012 session of the U.N. Human Rights Council approached, voices from within Sri Lanka and from the Tamil diaspora lobbied for the international investigation envisioned by the Panel of Experts report. The regime pushed back hard on the diplomatic front, emphasizing its rights as a sovereign state and the supremacy of domestic remedies. "We have the capability and the will to solve our own problems," said the Foreign Minister. ${ }^{63}$ The government pointed to the LLRC as evidence that it was handling the matter domestically, and as the Human Rights Council meeting drew closer, attempted to double down on this strategy. While still denying the validity of all allegations of war crimes, the Ministry of Defence had disclosed for the first time in August 2011 that its claims of a "zero civilian casualty rate" were inaccurate.

This admission enabled Sri Lanka, one month before the Human Rights Council met, to announce that an "army court of inquiry" had been convened to investigate allegations of war crimes and that a court martial would try anyone for whom the court found prima facie evidence of involvement in violations of international law. ${ }^{64}$ But when the Human Rights Council session passed

\footnotetext{
${ }^{61}$ Confidential Interview.

62 LLRC 2011.

63 Press Trust of India 2011.

${ }^{64}$ Sri Lankan Army Media Unit 2012.
} 
without an international investigation being empaneled, the army court of inquiry quietly closed up shop. Months later, it announced that the military was not responsible for any civilian casualties during the final phase of the war. Notably, it stated that:

"[A]t all stages of the Humanitarian Operation, the Sri Lanka Army behaved as a well-disciplined military force observing the International Humanitarian Law (IHL) and the law of war." 65

\section{iii. THE COMMISSION ON DisAPpeARANCES}

In May 2013, U.N. High Commissioner for Human Rights Navi Pillay announced she would conduct a visit to Sri Lanka. The announcement coincided with increased attention to Sri Lanka's human rights failures as a result of its selection as the host of the November 2013 Commonwealth Heads of Government Meeting (CHOGM). In the run-up to the meeting, the Canadian government, which boycotted the meeting, and others drew attention to Sri Lanka's abysmal human rights performance. Impunity for war crimes was the primary focus, and an addendum to all allegations about current abuses. Amidst the outcry, with Navi Pillay's visit around the corner, President Rajapaksa announced the creation of a new commission to investigate wartime disappearances in July 2013. ${ }^{66}$

Activists on the ground pointed out that creating institutions in response to international pressure had become par for the course for Sri Lanka, but that "they're only being used as a red herring, a cover-up, a way to give the appearance that something is being done" ${ }^{67}$ Many suggested

\footnotetext{
65 Sri Lankan Army Media Unit 2013.

${ }^{66}$ Gazette Extraordinary 2013.

${ }^{67}$ Human Rights Activist Interview.
} 
that they didn't expect the commission to ever actually get off the ground. "The key word is 'announced", said one, while another dismissed it as "just a ploy for CHOGM". ${ }^{68}$

\section{iv. FIVE YeARS Of INADEQUATE ACTION}

It is clear from the foregoing that the creation of each of these institutions was prompted by external pressure for accountability. Although they did not actually address responsibility for atrocities, they were non-trivial exercises into which the Sri Lankan government poured significant resources. The 2013 implementation plan for the LLRC called for an expenditure of nearly 1.3 billion Sri Lankan rupees or approximately $\$ 7.2$ million in today’s dollars, ${ }^{69}$ a not insubstantial proportion of the year's overall spending of 1.205 trillion rupees (just over $\$ 6.6$ billion). ${ }^{70}$ The following year, the government spent another rs 400 million ( $\$ 2.6$ million) on the Commission on Disappearances. $^{71}$

While approximately .1\% of total spending may not sound like a huge expenditure, it's worth noting that Sri Lanka budgeted only 5.4 billion rupees to its justice sector in $2013 .{ }^{72}$ In other words, the government spent about one-third as much on a sham transitional justice process as it did on its entire court system. Additionally, Sri Lanka's expenditures on these institutions are on par with what other countries transitioning out of conflict or autocracy have spent on robust accountability mechanisms. For instance, in 1995, South Africa spent \$18 million on its much-lauded Truth \& Reconciliation Commission in 1995, representing .06\% of the country's overall annual spending of

\footnotetext{
${ }^{68}$ Colombo Civil Society Interview (III), 2013. Colombo, August 8; Colombo Civil Society Interview (VI).

${ }^{69}$ Rajapaksa 2013.

70 Ministry of Finance 2012.

71 Sunday Times 2015.

72 The Gazette of the Democratic Socialist Republic of Sri Lanka 2012.
} 
$\$ 28$ billion. ${ }^{73}$ By contrast, Cambodia, which has a similarly sized economy and budget to Sri Lanka's, has dragged its feet and protested spending approximately $\$ 18.6$ million over a ten year period on its share of the expenses for the tribunal prosecuting Khmer Rouge leaders.

It was also clear at the time that the Sri Lankan government paid political costs to set up these institutions. The Rajapaksas' electoral strategy has always relied on their Sinhala-Buddhist "son of the soil" credentials and their ties to openly supremacist individuals and groups, including the militant monk outfit Bodu Bala Sena. But Sinhala-Buddhist supremacists objected strongly to the creation of any accountability institutions, however weak, on the grounds that they constituted an attack on the "war heroes". When the LLRC report was released, representatives of the hardline National Patriotic Movement publicly questioned the competence of the commissioners Rajapaksa had appointed. Monk-led mobs disrupted workshops on its implementation. ${ }^{74}$ One prominent former supporter, voicing a widely-held opinion, described the government's creation of human rights institutions as "groveling at the feet of the foreigners" and "betrayal of those who fought to save [Sri Lanka] from terrorism", ${ }^{75}$

Yet despite the resource and political costs incurred to operate them, these institutions were treated as utterly inadequate by those members of the international community calling for action. In the case of the LLRC, the governments of the U.S., the U.K, and Canada all highlighted the lack of any real inquiry into violations of international humanitarian law. ${ }^{76}$ The reception from international civil society was even more critical. Human Rights Watch observed that the report "disregard[ed] the worst abuses by government forces, rehash[ed] longstanding recommendations, and fail[ed] to

\footnotetext{
${ }^{73}$ Republic of South Africa Department of Finance 1995.

${ }^{74}$ Colombo Telegraph 2013.

75 Gunasekara 2013.

76 U.S. Department of State 2011; U.K. Foreign and Commonwealth Office 2012; Government of Canada 2012.
} 
advance accountability". ${ }^{77}$ Amnesty International described it as simply "the latest in a long line of failed domestic mechanisms in Sri Lanka". ${ }^{78}$

The response to the army court of inquiry and the commission on disappearances was even harsher. International human rights advocates stated that the court of inquiry's findings "stretch[ed] credulity"79 and demonstrated that accountability would be "next to impossible" to achieve domestically. ${ }^{80}$ During an official visit to Sri Lanka at which she was briefed on the work of the commission on disappearances, U.S. Assistant Secretary of State for South and Central Asian Affairs Nisha Biswal decried the "lack of progress" on "issues of justice and accountability". ${ }^{81}$

These reactions show that the institutions Sri Lanka created in response to international pressure were wholly unsuccessful at satisfying those actors calling for accountability. If the goal in setting up these bodies was silencing critics in the West and the international human rights community, they were a failure. But, as the next section demonstrates, Sri Lanka's actions were received very differently elsewhere.

\section{Playing to a Third-Party Audience}

\section{i. The InTERnAtional Politics OF ACCOUNTABILITY}

The withdrawal of aid that accompanied Western human rights pressure was met with a corresponding uptick in flows from alternative sources. China, which provided critical arms and support in the last stages of the war, ${ }^{82}$ had become Sri Lanka's single biggest aid donor by 2009,

\footnotetext{
${ }^{77}$ HRW 2011.

78 AI 2011.

${ }^{79}$ Sooka 2013.

${ }^{80}$ ICG 2013.

81 Biswal 2014.

82 With U.S. military assistance curtailed, and India refusing to supply offensive weaponry, Chinese arms sales to Sri Lanka increased "sevenfold" from 2006 to 2008. Samaranayake 2011. Contemporaneous reports also suggested that
} 
providing $\$ 1.2$ billion out of $\$ 2.2$ billion in total commitments. ${ }^{83}$ As then-foreign secretary, Palitha Kohona, put it in an interview with the New York Times, Sri Lanka's “traditional donors" in the West had "receded into a very distant corner" to be replaced by China. ${ }^{84}$

Unlike its bilateral relationships with the West, which the Rajapaksa regime perceived as "no carrots and all sticks", ${ }^{55}$ Chinese aid and infrastructure loans came with no governance or reform conditions attached. In Foreign Secretary Kohona's words, Chinese money was preferable because “Asians don't go around teaching each other how to behave." 86 The turn towards China also played into the broader regional dynamics of competition between China and India. The traditionally close relationship with India became strained in the post-war years, in part due to India's advocacy for human rights and increased self-governance for Sri Lanka's Tamils. Rajapaksa exploited his resistance to Indian pressure on Tamil issues to shore up support among his Sinhala-Buddhist nationalist constituency. At the same time, he used Chinese loans to fund massive infrastructure projects in his southern support base, including an airport and deep-water port at his hometown of Hambantota.

The regime assiduously cultivated the relationship with China, for example boycotting the Nobel Peace Prize ceremony for Chinese dissident Liu Xiabao in 2010. In 2011, after the U.N. Panel of Experts report came out, the Chinese Foreign Minister spoke up on Sri Lanka's behalf, saying

\footnotetext{
Pakistan's increase of military assistance loans, arms sales, and training to Sri Lanka's Air Force were the direct result of Chinese pressure. Chellany 2009.

83 Sri Lanka Ministry of Finance and Planning \& the Treasury 2010. "2010 Pre-Election Budgetary Position Report," March 1, 2010. Available at http://www.treasury.gov.lk/docs/pressrelease/preElection-budgetary-2010.pdf

${ }^{84}$ Sengupta 2008.

${ }^{85}$ Committee on Foreign Relations 2009.

86 Sengupta 2008.
} 
that China was “confident" in Sri Lanka's ability to address the matter internally, and calling on the international community to refrain from "taking measures that could further complicate the issue". ${ }^{87}$

The staunch support of China and the diminishing dependence on Western donors allowed Sri Lanka some breathing room from accountability pressure. Furthermore, although the alleged deaths of more than 40,000 Tamil non-combatants during the final months of the war represented deliberate violence against civilians on a scale rarely matched, international reaction was relatively muted, ${ }^{88}$ possibly as a consequence of Sri Lanka's success in framing its fight against the LTTE as counter-terrorism. ${ }^{89}$ In the post-war period, while vocal about the unacceptability of war crimes going uninvestigated, Western governments were reluctant to take responsibility for ensuring accountability themselves. U.S. Department of State spokeswoman Victoria Nuland outlined the U.S. position in late 2011: “[W]e've long said that it is better for Sri Lankans to take these issues themselves and address them fully ... So let's see what they are willing to do going forward". ${ }^{90}$

This wait-and-see approach, despite the fact that no perpetrators of mass atrocities anywhere have ever prosecuted themselves, reflects the potentially high price of pursuing accountability, in terms of the resources and political capital that would be expended pushing for an international tribunal or pursuing universal jurisdiction prosecutions. These costs also motivated the Western preference to work through multilateral institutions, which, because of the constraints on action by the U.N. Security Council or the International Criminal Court, meant the U.N. Human Rights

\footnotetext{
87 http://www.dailymirror.lk/11162/-china-backs-sri-lanka-

${ }^{88}$ Compare, for instance, the robust international response to the other widely-reported mass killing event of 2009: the Guinean stadium massacre described in the introduction above.

${ }^{89}$ Nadarajah 2018.

90 U.S. Department of State 2011.
} 
Council. Led by the United States, Western countries pushed for the Human Rights Council to adopt a strong resolution that would empanel an international investigation.

\section{ii. A Coalition-Blocking Strategy}

No state has a veto power on the Human Rights Council. Its 47 members are elected to three-year terms by the U.N. General Assembly and are distributed according to the regional blocks. The Western European and Others Group (WEOG) holds only seven seats. This means that resolutions, which pass by a simple majority, must secure the support of a broad coalition of states.

Exploiting these dynamics, the Rajapaksa regime mounted a vigorous campaign to block the Human Rights Council from mandating an international investigative body. Sri Lanka's diplomacy took aim at the non-Western council members. It had two components. The first was to talk up its "home-grown" institutions. The second was to characterize criticism of them as illegitimate and invoke developing world solidarity against Western oppression. These two strategies worked in tandem to provide peer states on the Human Rights Council cover for supporting Sri Lanka as well as a reason to do so.

\section{a) HOME-GROWn MECHANISMS}

The emphasis on a "home-grown" approach focused primarily on the LLRC. Speaking to the September 2011 session of the Human Rights Council, the head of Sri Lanka's delegation emphasized that the LLRC members were "highly regarded professionals" and said they "should be given time and space to come up with their findings and recommendations". ${ }^{91}$ He echoed this call for time and space in March 2012, when he warned a ministerial-level audience about undermining an "effective ongoing domestic process". He went into significant detail aimed at demonstrating that

\footnotetext{
${ }^{91}$ Samarasinghe 2011.
} 
the LLRC's hearings were conducted rigorously and transparently and stated that "Sri Lanka is best placed to successfully conclude a home grown process of reconciliation acceptable to, and benefitting all of its people". ${ }^{92} \mathrm{He}$ also highlighted the creation of the army court of inquiry, saying "Sri Lanka has taken clear and definite steps towards implementation of the recommendations of the [LLRC], barely two months after the report was made public". ${ }^{93}$

In 2013, when Sri Lanka was again up for consideration by the Human Rights Council, its representatives continued to hold up the "home-grown reconciliation mechanism" as sufficient to address accountability concerns. ${ }^{94}$ They challenged the resolution before the Council on the grounds that it would "undermine or devalue ongoing processes" (i.e. the implementation of the LLRC's recommendations) by suggesting that they were "somehow deficient". 95

Following High Commissioner Pillay's critical report on her August 2013 country visit, the Sri Lankan Ambassador to Geneva told the Human Rights Council that: "Multiple mechanisms to address accountability ha[d] been put in place and are in motion". He referred specifically to the recently-announced Commission on Disappearances, claiming that "all reported cases of disappearances are being comprehensively investigated". ${ }^{96}$ And in the run up to the March 2014 session, Sri Lanka issued a lengthy written reply to the High Commissioner's report, which in addition to the LLRC, the army court of inquiry, and the Commission on Disappearances, also highlighted investigations into two 2006 massacres. ${ }^{97}$

\footnotetext{
92 Samarasinghe 2012a.

93 Samarasinghe 2012a.

94 Aryasinha 2013b.

95 Samarasinghe 2013.

96 Aryasinha 2013c.

97 Permanent Mission of Sri Lanka 2014.
} 


\section{b) CRITICIZING THE WEST}

Sri Lanka's efforts to foreground its domestic mechanisms were almost always accompanied by harsh criticism of Western accountability pressure as "a witch hunt"" and a "systematic and organized campaign aimed at distorting and misinforming". 99 This began in 2011, when High Commissioner Pillay called for an international investigation into the allegations contained in the Panel of Experts report. Sri Lanka's Ambassador to Geneva immediately denounced her “demonstrable lack of objectivity and impropriety". ${ }^{100}$

Shortly thereafter, his successor said of Amnesty International and other advocacy organizations: "It is evident that the real aim of those questioning the legitimacy of LLRC is to undermine the principle of State sovereignty". ${ }^{101}$ Sovereignty would become a persistent theme of Sri Lanka's rhetoric. In 2012, with discussions about a resolution underway, the head of the delegation asked the members of the Human Rights Council if they would "permit a usurpation of an independent nation's prerogative to act in its people's paramount interests". ${ }^{102}$ The Ambassador explained Sri Lanka's strategy to the press: "Developing countries fear that such a decision would set a precedent giving an historic character to the Council permiting [sic] a powerful country, for reasons of its own, to reopen a dossier that has been closed to examine past violations". ${ }^{103}$

Sri Lanka's diplomats emphasized to their peer states that they could be next. "Today it is Sri Lanka," warned Minister Samarasinghe in 2013. "Tomorrow, it may be any other country in this

\footnotetext{
98 Asian Tribune 2012.

99 Samarasinghe 2012b.

100 Senewiratne 2011.

101 Kunanayakam 2011.

102 Samarasinghe 2012.

103 Daily FT 2012.
} 
Council'. ${ }^{104}$ As the Human Rights Council debated the draft resolution in 2013, Sri Lanka's ambassador cautioned that it could "have an adverse impact on all developing countries". ${ }^{105} \mathrm{He}$ reiterated his warning in 2014, adding that the proposal to empanel an international inquiry was "highly intrusive in nature and ... in breach of sovereignty of the Sri Lankan people and territorial integrity of Sri Lanka”. ${ }^{106}$

Sri Lanka also advanced this rhetoric outside of Geneva. Speaking at the 2013 U.N. General Assembly in New York, President Rajapaksa decried the "relentless pursuit" of Sri Lanka as part of a "growing trend in the international arena, of interference by some, in the internal matters of developing countries, in the guise of security, and guardians of human rights". ${ }^{107}$ And as the March 2014 Human Rights Council session approached, he reached out personally to the sub-Saharan African members, calling for developing world solidarity against neo-imperialist human rights pressure. ${ }^{108}$ In a statement to the press, he memorably characterized Western calls for an international inquiry as mean-spirited bullying, "like Cassius Clay playing against a schoolboy". ${ }^{109}$

\section{c) THE SuCCESS OF THE STRATEGY (AND ITS LIMITS)}

In both 2012 and 2013, Colombo managed to stave off an international inquiry. The LLRC's report had been released just in time to muddy the waters for the March 2012 Human Rights Council session. The announcement of the army court of inquiry immediately preceding the session was another thumb on the scale. Discussing the court of inquiry with me in 2013, one member of

\footnotetext{
104 Samarasinghe 2013.

105 Aryasinha 2013a.

106 Aryasinha 2014.

107 Rajapaksa 2013.

108 Author's field notes, Geneva, March 2014.

109 Aneez 2014.
} 
Sri Lankan civil society agreed that while it was an attempt to "pull the wool over the eyes of some international actors", it was not aimed at those calling for accountability. Rather, it was targeted at still-undecided Human Rights Council members. If Sri Lanka could “pick off” some of these states in the run-up to the March 2012 session, it would improve the chances of defeating a resolution. ${ }^{110}$

With Sri Lanka's diplomats touting its "home-grown" mechanisms and challenging Western pressure, the majority of the Human Rights Council was disinclined to empanel an investigation. India's declaration that it would maintain a "policy of not interfering into the internal matters of a country" "was particularly helpful as, in the words of one diaspora activist, "other countries look to India to signal how to respond" on Sri Lanka issues. ${ }^{112}$ In the face of these dynamics, the U.S., leading the push for accountability, backed down. Instead of pushing for an international investigation, it put on the table what it described as "a moderate and balanced resolution" 113 calling on Sri Lanka to implement the recommendations of the LLRC despite its weakness on accountability. The new language did not include any mention of the U.N. Panel of Experts report.

Despite an oral revision to give Sri Lanka final say over any "advice and technical assistance" provided by the U.N., the Rajapaksa administration still fought the passage of the watered-down resolution. And although it passed (and was reiterated in 2013), the public debates in the Human Rights Council revealed how deeply the narratives of home-grown methods and Western interference had penetrated. ${ }^{114}$ In their explanation of "no" votes in 2012, developing states emphasized that domestic mechanisms must take precedence over international (Uganda, Indonesia)

\footnotetext{
110 Colombo Civil Society Member Interview (II). 2013. Colombo, August 8.

111 Krishna 2012.

112 Tamil Diaspora Activist Interview (I).

113 U.S. Representative to the UNHRC 2012.

114 Information on member votes and statements cited in this section is from the author's notes, either from attendance at the relevant UNHRC session or watching the UN Web TV telecast.
} 
and that "Sri Lanka's home-grown process should be prioritized" (Thailand). Many also argued that Sri Lanka must be given more time and space to implement the LLRC (Maldives, Kyrgyzstan) and that the resolution risked "undermin[ing] national efforts currently underway" (Cuba, on behalf of those voting against). Others criticized the "biased approach" of the international community (Ecuador, Bangladesh).

Similar dynamics prevailed during the March 2013 debate. Once again, the language of the resolution was weakened at the eleventh hour, so that it simply "encourage[ed]" Sri Lanka to take action. ${ }^{115}$ And once again, the "no" votes emphasized the "ongoing domestic reconciliation process" (Russia, on behalf of those voting against) and criticized the "biased" nature of Western calls for accountability (Venezuela, Belarus).

In the March 2014 debate following High Commissioner Pillay's formal presentation of her country visit report, member states again parroted the Sri Lankan rhetoric about "home-grown methods" and Western bias. Several criticized the High Commissioner's "discriminatory approach" (Pakistan) and the "politicization" of the process (Venezuela). They highlighted concerns that the international investigation she called for would "undermine" the domestic process (Namibia, India, Indonesia). And following President Rajapaksa's diplomatic offensive, which called for developing world solidarity, at least two African states abandoned their plans to support the resolution mandating an international inquiry. ${ }^{116}$

But Sri Lanka's luck had run out. On March 27, with a plurality of 23 out of 47 votes in favor, the Human Rights Council passed resolution 25/1. It requested that the High Commissioner "undertake a comprehensive investigation into alleged serious violations and abuses of human rights

\footnotetext{
115 UNHRC 2013.

116 Author's field notes, Geneva, March 2014.
} 
and related crimes by both parties in Sri Lanka during the period covered by the Lessons Learnt and Reconciliation Commission". ${ }^{117}$

The resolution was a loss for Sri Lanka, but the Rajapaksa government had successfully delayed any international action on post-conflict justice for five years and prevented a stronger international response. As one Tamil activist lamented, the regime's ability to convince members of the international community to prioritize disingenuous domestic remedies was a huge success as a "time-buying activity". ${ }^{118}$ And although an inquiry was ultimately empaneled, the delay was time the regime had to destroy evidence, bulldoze mass graves, intimidate and disappear witnesses, and appoint accused perpetrators to ambassadorial posts where they had diplomatic immunity.

The success of this strategy rested on swaying the audience of non-activist states on the Human Rights Council. And while some of the states that parroted Sri Lanka's rhetoric would likely always have been "no" votes, a number of them were demonstrably swing states. Indonesia, for example, sided with Sri Lanka to vote against the 2012 and 2013 resolutions, but abstained in 2014 . Likewise Botswana, which abstained in 2012 and 2013, shifted to a "yes" vote in 2014. Others, such as Uruguay, Mexico, and Nigeria, that voted "yes" in 2012 and 2013, were explicit that they would not support the stronger language favored by the West. They emphasized the importance of the domestic mechanisms that Sri Lanka had set up. By creating institutions tangentially related to accountability and then emphasizing the primacy of domestic processes and sovereignty against Western interference, Sri Lanka was able to prevent many of its peer states from joining the Western push for robust action, and to convince some of them to vote against even the weakened resolutions that passed in 2012 and 2013.

\footnotetext{
117 UNHRC 2014.

118 Tamil Activist Interview, Jaffna, November 2013.
} 


\section{CONSIDERING ALternative Explanations}

I have argued that Sri Lanka's creation of half measures institutions in response to accountability pressure was part of a strategy to disrupt the formation of a coalition on the U.N. Human Rights Council that would support an international investigation into state crimes. However, there are at least two other plausible explanations for half measures of the sort Sri Lanka employed. In this section, I address the possibility that the creation of these institutions was either (1) driven by domestic demand for particular forms of accountability institutions, or (2) part of a good faith, but inadequate effort to comply with international demands. I argue that the available evidence weighs heavily against either interpretation.

\section{A. The Domestic Politics of AcCountability}

Transitional justice institutions that fail to meet international standards often deviate from "best practices" because they are responding to domestic political imperatives. In Sri Lanka, domestic politics clearly militated against the creation of any accountability mechanism, for three reasons. First, the Rajapaksa regime's core electoral constituency of Sinhala-Buddhist voters opposed any admission or investigation of war crimes. Second, perpetrators of alleged atrocities remained in power. And third, there were ongoing reports of widespread and systematic abuses of human rights. The result, as I outline below, is that not only was there no domestic constituency pushing for accountability, the regime's pursuit of half measures required a delicate balancing act to avoid jeopardizing its hold on power.

Just six months after the war's end, Mahinda Rajapaksa called presidential elections approximately two years ahead of schedule. On the strength of the defeat of LTTE, he won handily, 
polling at nearly $80 \%$ throughout most of the Sinhala-Buddhist south and west. ${ }^{119}$ Many in the south had understood the military victory not only as a defeat of terror, but as a vindication of SinhalaBuddhist supremacist ideology. The LTTE were viewed as an external incursion, the "invaders from the North" of militant Buddhist rhetoric. ${ }^{120}$ Tamil victims of war crimes were therefore not legitimate subjects of the Sri Lankan state deserving of justice, but a defeated enemy. Most Sinhalese bought the official line that the campaign had been conducted with a "zero civilian casualty" profile. When pressed on the absurdity of the claim, some admitted that civilians died, but insisted that any deaths were "justified". ${ }^{121}$

The triumphant military were heroes to the Sinhalese public. As a Tamil activist put it in 2013, it was simply not an option to "point a finger at the army". It would "be deemed to be unpatriotic" by the Sinhalese. ${ }^{122}$ In the 2010 election, when opposition candidate General Sarath Fonseka publicly accused Gotabaya Rajapaksa of ordering war crimes, it backfired spectacularly. ${ }^{123}$ Many in the Sinhala-Buddhist south viewed him as a traitor who had sold out his own men. President Rajapaksa was careful to guard against being similarly perceived himself, repeatedly assuring the military "we will not betray you". ${ }^{124}$

As noted above, ${ }^{125}$ Rajapaksa's creation of the LLRC and other institutions met with significant resistance from within his own support base, who felt that he was caving to foreign

\footnotetext{
119 In the Tamil majority Northern Province, he lost by large margins.

120 McGowan 2012.

121 Author's field notes, Colombo 2013; Author's field notes, Southern Province, 2014.

122 Tamil Activist Interview, London, October 23, 2013

123 Not only did Fonseka lose the election, he landed in prison for years, first on fraud charges, then on charges that his allegation against Gotabaya threatened national security.

124 Sri Lanka Army 2011.

125 See section IV.B.iv.
} 
pressure. And when, following the 2014 Human Rights Council resolution, he expanded the mandate of the Commission on Disappearances, the opposition was quick to pounce. The United National Party demanded the public be told "why President Mahinda Rajapaksa, who boasted he would sit in an 'electric chair' than betray soldiers (sic), has now done an about turn". ${ }^{126}$

The political importance of loyalty to the troops reflected not only popular sentiment, but the defense establishment's increased power in the post-war period. By 2009, the military was a huge organization, over a hundred times larger than the force of 3500 with which it entered the war in 1983. As a former high-level commander cautioned, such a large force made it "difficult to convert to peacetime", ${ }^{127}$ After the war, high-ranking members of the military invested heavily in the economy, and lower-ranking members were given incentives to open businesses. One Colombo entrepreneur spoke of losing his government contracts to an army-owned competitor and said that it was virtually impossible for small businesses to outcompete military companies. ${ }^{128}$

The expansion of the role of the military in post-war Sri Lanka was accompanied by a vicious crackdown on domestic civil society. Sri Lanka became one of the most dangerous places in the world to be a journalist. Sri Lankan NGOs were labeled "traitors", "terrorists", or "shills for foreign powers". ${ }^{129}$ Rumors circulated that the regime had created a special unit of the police to investigate individuals suspected of providing human rights information to the U.N. and

\footnotetext{
126 Sunday Times 2014.

127 Former Army Commander Interview, Colombo, August 14, 2013.

128 Sinhalese Businessman Interview. 2013. Colombo, August 6.

129 The Economist 2014.
} 
international NGOs. ${ }^{130}$ The result was that domestic advocacy for accountability was almost completely absent, "with even civil and peace groups saying it's better to leave alone". ${ }^{131}$

The ascendancy of nationalist and militaristic sentiment, along with the silencing of critical voices, meant that the Sinhalese population and its political representatives were intense hostile towards accountability. Because the Rajapaksas' electoral strategy relied upon their tight links to the victorious army, pursuing accountability would have been politically risky even if high-level officials were not themselves implicated in international crimes. Even in the event of regime change, one civil society leader argued in 2013, a future administration would also be reluctant to "jeopardize relations with the army." 132 But senior government officials' own alleged complicity in war crimes and ongoing abuses made the possibility of justice even more fraught. As another activist noted in 2013, predicting that the Rajapaksa administration would not budge on accountability: "They have a lot to lose". 133

\section{B. INADEQUATE GOOD FAITH EFFORTS}

Where inadequate transitional justice institutions cannot be explained by domestic political demand, they may instead reflect genuine efforts to meet international standards that fail due to low capacity. However, this explanation also cannot account for Sri Lanka's behavior. The Rajapaksa regime signaled clearly that it was not making a good faith effort to supply accountability. It consistently denied allegations of war crimes and rejected international demands for justice. This began in the weeks immediately following the war's end, with President Rajapaksa giving an

\footnotetext{
130 Author's field notes, Colombo, March 2014.

${ }^{131}$ Harrison 2013.

132 Colombo Civil Society Member Interview (II).

133 Colombo Civil Society Member Interview (VI).
} 
interview to Time in which he characterized accusations of war crimes as "propaganda". ${ }^{134}$ A few months later, a government minister accused the U.N. Special Rapporteur for Extrajudicial Killings of being "at the heart of a terrorist media campaign against the Sri Lankan Government". ${ }^{135}$

This behavior only intensified as international pressure increased. When the U.N. Panel of Experts report came out, the regime lashed out at civil society members suspected of contributing and accused them of underhanded attempts at regime change. ${ }^{136}$ By 2013 , the government was routinely throwing public tantrums in response to accountability pressure, even as it continued to unveil new half measures institutions. A prominent civil society leader put it starkly: "The official position is absolutely hostile and dismissive." ${ }^{\text {137 }}$ When High Commissioner Pillay arrived for her country visit, the government mounted a campaign to undermine her. One activist who was involved in her visit described this as "coordinated, pre-planned, deliberate government strategy" to "humiliate and discredit her". ${ }^{138}$ The regime was equally vitriolic in response to the pressure surrounding the Commonwealth Heads of Government Meeting later that year. In the angry words of the communications minister: "We are a sovereign nation. You think someone can just make a demand from Sri Lanka?" "139 And in early 2014, when the U.S. Assistant Secretary of State for South and Central Asian Affairs warned that "patience [wa]s wearing thin", the Sri Lankan government

\footnotetext{
134 Thottam 2009.

135 Wijesinha 2009.

136 Colombo Civil Society Member Interview (III).

137 Colombo Civil Society Member Interview (III).

${ }^{138}$ Human Rights Activist Interview, October 2013.

139 BBC News 2013.
} 
reacted furiously, accusing the international community of "setting the groundwork to hang our President" ${ }^{\prime 140}$ and refusing a visa to the U.S. Ambassador for Global Women's Issues in retaliation. ${ }^{141}$

These actions indicate that Sri Lanka was actively resisting demands for justice. And it is clear that international actors calling for accountability interpreted Sri Lanka's creation of half measures institutions as disingenuous. Following the release of the LLRC report, the members of the U.N. Panel of Experts argued that it "cast serious doubt on [Sri Lanka's] willingness to uncover what really happened in those fateful months". ${ }^{42}$ Human Rights Watch dismissed the entire exercise as "playing for time". ${ }^{143}$ International Crisis Group went further, decrying it as an attempt to "exonerate the government" and "roll[ back well-established principles of international law". ${ }^{44}$ They spoke similarly about the army court of inquiry - "a transparent ploy to deflect a global push for a genuine international investigation", ${ }^{145}$ and the commission on disappearances - "throwing bones to the international community". ${ }^{146}$ In 2014, when Sri Lanka announced that it would not permit the investigators mandated by the Human Rights Council resolution to enter the country, and proscribed 16 Tamil diaspora organizations and more than 400 individuals, local activists and international audiences understood these measures as an effort to control the flow of information to the international investigation. ${ }^{147}$

\footnotetext{
140 Colombo Gazette 2014.

141 Aneez \& Sirilal 2014.

142 Darusman et al. 2012.

143 HRW 2011.

144 ICG 2011.

145 HRW 2012b.

146 HRW 2013.

147 Author's field notes, Geneva, March 2014.
} 


\section{DisCuSSION AND CONCLUSION}

Sri Lanka's refusal to investigate and prosecute those responsible for mass atrocities has been a source of contention with the West since the alleged war crimes first came to light in 2009 . Domestic political constraints made the provision of justice an extremely unappealing prospect for the post-war government. And resistance to international involvement, due in part to the complicity of members of the ruling regime in the alleged atrocities, made cooperation with an international accountability mechanism even less attractive. Nevertheless, in the fact of sustained international pressure, the regime spent millions of dollars on a succession of weak accountability institutions, drawing invective from their staunchly nationalist constituency, which felt they were caving to international pressure. The reactions of international audiences demonstrate that the domestic mechanisms rolled out by Sri Lanka were unconvincing to the actors invested in demanding justice.

Sri Lanka's behavior therefore exemplifies the question posed in the introduction: Why pay the costs to create human rights institutions that don't satisfy those demanding action? As in the Guinea and Bahrain examples, Sri Lanka continued to face criticism and pressure from Western governments and international NGOs. However, peer states on the U.N. Human Rights Council had a very different reaction. Coupled with rhetoric portraying itself as "this poor third-world country" bullied by Western governments, ${ }^{148}$ Sri Lanka pointed to the creation of half measures institutions as evidence that it was acting domestically. The strategy paid off. Even after the 2014 resolution authorizing an investigation, Sri Lanka's allies on the Council continued to protest the move as "unwarranted, especially in the context where the country is implementing its own domestic processes" and a potentially "dangerous precedent], which may adversely affect all our countries". ${ }^{49}$

\footnotetext{
148 Associated Press 2014.

${ }^{149}$ Like Minded Group 2014.
} 
The case study provides support for the theory that repressive states use human rights half measures as a coalition-blocking strategy. Sri Lanka's behavior is hard to explain otherwise. In many cases, human rights behavior that doesn't measure up to international standards can be easily explained through the lens of domestic politics - e.g. the issuance of an amnesty for popular leaders in an otherwise vigorous truth and reconciliation process. But here, domestic political incentives clearly militated in favor of doing nothing on accountability. Likewise, a story of norms and pressure triggering good-faith, but inadequate, efforts to comply doesn't match the facts either. Sri Lanka was openly antagonistic to international advocacy on war crimes and the skeptical response of activist states and international NGOs demonstrates that they understood Sri Lanka's behavior as bad faith. Finally, the literature on insincere human rights commitments offer some traction on Sri Lanka's motivation. But creating and operating institutions, even disingenuous ones, is significantly more costly behavior than signing onto a treaty. A "cheap talk" story therefore misses important dynamics and leaves the essential puzzle unanswered: Why would a state that strongly prefers inaction go to the trouble of creating costly human rights institutions that do not satisfy those pushing for action?

The theory presented here explains this behavior as a reasonable gamble on escaping punishment for noncompliance, while still avoiding the full costs of meeting human rights obligations. It makes several contributions to international relations scholarship. First, in intervenes in a growing literature on how repressive states push back against the international human rights project. Second, it theorizes a new audience for human rights behavior. Third, it elucidates the role of the U.N. Human Rights Council as a venue for framing contests and rhetorical competition. And fourth, it suggests a novel role for hypocrisy in international relations, of protecting an audience's reputation. The evidence from Sri Lanka supports the theoretical predictions that pursuing half 
measures in response to international human rights pressure can be a successful strategy even when it doesn't satisfy those supplying the pressure. Half measures work by simultaneously persuading swing states that can act as veto points on multilateral action to give their support and offering them the political cover to do so.

The case of Sri Lanka presented here exemplifies a set of especially hard cases for human rights enforcement - violator governments who are protected by a Security Council veto-holding patron. The importance of this set of cases, in which contention over international action necessarily shifts to the Human Rights Council, is underscored by the more recent cases of massive violations of human rights in Syria and Burma, protected by Russia and China respectively. But half measures strategies are not unique to this set of cases. Indeed, they should be increasingly attractive to violator states as the U.S. retreat from its historical rights-promoting role makes enforcement more uncertain and more dependent on multilateral action outside the Human Rights Council as well as inside. These dynamics will only increase the benefit to be gained by violator governments of recruiting the support of their peer states.

And while the relevance of such coalition-blocking behavior is particularly clear in the context of framing competitions over how human rights behavior should be characterized, it extends to other areas of international relations in which the enforcement of international rules requires other states to act in the absence of a self-interested motivation to do so. In issue areas ranging from international environmental law to anti-corruption efforts, the absence of reciprocal benefits from other states' compliance means states have little incentive to monitor and enforce international rules. The result is that enforcement often requires multilateral action, opening up opportunities for violator states to deploy half measures strategies in an attempt to block the formation of coalitions. 


\section{REFERENCES}

Amnesty International. 2011. "When Will They Get Justice? Failures of Sri Lanka's Lessons Learnt and Reconciliation Commission." September 7.

. 2015. "Behind the Rhetoric: Human Rights Abuses in Bahrain Continue Unabated.” April 16.

Aneez, Shihar. "Sri Lanka's president denounces U.S. plan for rights resolution.” Reuters. February 28, 2014.

Aneez, Shihar and Ranga Sirilal. 2014. "US: Sri Lanka refuses visa for State Dept official after war crimes accusations." Reuters. February 4.

Aryasinha, Ravinatha. 2013a. Intervention at the Informal Meeting on the Draft Resolution on 'Promoting Reconciliation and Accountability in Sri Lanka'. UNHRC, 22, Regular Session. March 8.

. 2013b. Statement of Sri Lanka. UNHRC, 23 ${ }^{\text {rd }}$ Regular Session. May 27.

. 2013c. Statement of Sri Lanka. UNHRC, 24rd Regular Session. September 25.

. 2014. Intervention at the first informal meeting called by the sponsors of the draft resolution on Sri Lanka. UNHRC, 25 th Regular Session. March 7.

Asian Tribune. 2012. “Vested Groups' Intention of Interfering in Sri Lanka’s Internal Affairs Exposed.” March 6.

Associated Press. 2014. "War crimes: New UN probe puts pressure on Sri Lanka.” June 30.

Bass, Gary. 2016. "Bargaining Away Justice: India, Pakistan, and the International Politics of Impunity for the Bangladesh Genocide." International Security 41(2): 140-87.

BBC News. 2013. “Chogm: Sri Lanka’s Mahinda Rajapaksa hits out at critics.” November 14.

Bennett, Andrew. 2010. "Process Tracing and Causal Inference." In Rethinking Social Inquiry: Diverse Tools, Shared Standards, 2nd ed., ed. Henry E. Brady and David Collier, 207-19. Lanham, MD.: Rowman and Littlefield.

Biswal, Nisha Desai. 2014. "Press Conference on Status of Human Rights in Sri Lanka.” February 2.

Cardenas, Sonia. 2007. Conflict and Compliance: State Responses to International Human Rights Pressure. Philadelphia: University of Pennsylvania Press.

Chellany, Brahmy. 2009. "China fuels Sri Lankan war.” The Japan Times. March 4.

Collier, David. 2011. "Understanding Process Tracing.” PS: Political Science and Politics 44(4): 823-30.

Colombo Gazette. 2014. “War crimes attempt on MR.” January 29.

Committee on Foreign Relations, United States Senate. 2009. Sri Lanka: Recharting U.S. Strategy After the War. One Hundred Eleventh Congress: First Session. December 7.

Cronin-Furman, Kate. 2017. "How to Get Away with Mass Murder: Denying Mass Atrocities in Sri Lanka and Syria." War on the Rocks. May 18.

Dai, Xinyuan. 2005. “Why Comply? The Domestic Constituency Mechanism. International Organization 59(2): $363-98$.

Daily FT. 2012. "UNHRC battle will be fought to the very last minute.” March 10.

Darusman, Marzuki, et al. 2011. Report of the Secretary General's Panel of Experts on Accountability in Sri Lanka. March 31. 2012. "Revisiting Sri Lanka’s Bloody War.” The New York Times. March 2.

Downes, George W., David M. Rocke, and Peter N. Barsoom. 1996. "Is the Good News About Compliance Good News About Cooperation?” International Organization 50(3): 379-406.

Economist. 2014. “Sri Lanka and human rights: Never a good time.” March 21. 
Franklin, James C. 2008. "Shame on You: the Impact of Human Rights Criticism on Political Repression in Latin America. International Studies Quarterly 51(1): 187-2011.

George, Alexander L., and Andrew Bennett. 2005. Case Studies and Theory Development in the Social Sciences. Cambridge, MA: MIT Press.

Gerring, John. 2007. "Is There a (Viable) Crucial-Case Method?” Comparative Political Studies 40(3): 231-53.

Hafner-Burton, Emilie. 2008. "Sticks and Stones: Naming and Shaming the Human Rights Enforcement Problem." International Organization 62(4): 689-716.

Hafner-Burton, Emilie. 2013. Making Human Rights a Reality. Princeton: Princeton University Press.

Hafner-Burton, Emilie \& James Ron. 2009. "Seeing Double: Human Rights Impact Through Qualitative and Quantitative Eyes.” World Politics 61(2): 260-401.

Hafner-Burton, Emilie \& Kiyoteru Tsutsui. 2005. "Human Rights in a Globalizing World: The Paradox of Empty Promises.” American Journal of Sociology 110(5): 1373-1411.

Harrison, Frances. 2013. Still Counting the Dead: Survivors of Sri Lanka's Hidden War. London: Portobello Books.

Hathaway, Oona. 2002. “Do Human Rights Treaties Make a Difference?” Yale Law Journal 111(8): 1935-2042.

Hathaway, Oona. 2007. "Why Do Countries Commit to Human Rights Treaties?” Journal of Conflict Resolution 51(4): 588621.

Hawkins, Darren and Wade Jacoby. 2010. "Partial Compliance: A Comparison of the European and Inter-American Courts of Human Rights.” Journal of International Law and International Relations 6(1): 35-85.

Hillebrecht, Courtney. 2014. "The Power of Human Rights Tribunals: Compliance with the European Court of Human Rights and Domestic Policy Change.” European Journal of International Relations 20(4): 1100-1123.

Human Rights Watch. 2009. "Sri Lanka: Urgently Evacuate Civilians." March 5.

2011. "Sri Lanka: Report Fails to Advance Accountability.” December 16.

2012a. "UN Rights Council: Sri Lanka Vote a Strong Message for Justice.” March 22.

2012b. “Sri Lanka: Army Inquiry a Delaying Tactic.” February 15.

2013. “Sri Lanka: No Justice in Aid Worker Massacre.” July 31.

2015. "The Blood of People Who Don't Cooperate: Continuing Torture and Mistreatment of Detainees in Bahrain." November 22.

International Alert. 2013. "Dynamics and Trends of Foreign Aid in Sri Lanka." August.

International Crisis Group. 2011. "Statement on the Report of Sri Lanka's Lessons Learnt and Reconciliation Commission.” December 22.

2012. “Sri Lankas North I - The Denial of Minority Rights.” March 16, 2012.

2013. “Sri Lanka’s Authoritarian Turn: The Need for International Action.” February 20.

Krain, Matthew. 2012. “J'accuse! Does Naming and Shaming Perpetrators Reduce the Severity of Genocides or Politicides?” International Studies Quarterly 56(3): 574-589.

Krasner, Stephen D. 1993. "Sovereignty, Regimes, and Human Rights.” In Regime Theory and International Relations. Oxford: Clarendon Press. 1999. Sovereignty: Organized Hypocrisy. Princeton: Princeton University Press. 
Krebs, Ronald R. and Patrick Thaddeus Johnson. 2007. “Twisting Tongues and Twisting Arms: The Power of Political Rhetoric.” European Journal of International Relations 13(1): 35-66.

Lebovic, James H. \& Erik Voeten. 2009. "The Cost of Shame: International Organizations and Foreign Aid in the Punishing of Human Rights Violators.” Journal of Peace Research 46(1): 79-97.

Lessons Learnt and Reconciliation Commission. 2011. Final Report. November 15.

Like Minded Group. 2014. Joint Statement. September 26.

Mahoney, James. 2010. “After KKV: The New Methodology of Qualitative Research.” World Politics 62 (1): 120-47.

McGowan, William. 2012. "Buddhists Behaving Badly.” Foreign Affairs. August 2.

Murdie, Amanda \& David R. Davis. 2012. "Shaming and Blaming: Using Events Data to Assess the Impact of Human Rights INGOs. International Studies Quarterly 56(1): 1-16.

Nadarajah, Suthaharan. 2018. “The Tamil Proscriptions: Identities, Legitimacies and Situated Practices.” Terrorism and Political Violence 30(2): 278-297.

Nasaw, Daniel. 2009. "Sri Lanka blasts US report on human rights abuses." The Guardian. October 22.

Neumayer, Eric. 2005. "Do international human rights treaties improve respect for human rights?” Journal of Conflict Resolution 49(6): 925-953.

Permanent Mission of Sri Lanka to the United Nations Office at Geneva. 2013. Press Release. March 22. 2014. Comments received from the Permanent Mission of Sri Lanka. A/HRC/25/G/9. February 24.

Press Trust of India. 2011. "Sri Lanka rejects demand for international probe into war crimes." December 14.

Rajapaksa, Mahinda. 2012. “Budget Speech: 2013.” November 8. . 2013a. The Gazette of the Democratic Socialist Republic of Sri Lanka No. 1823/42. August 15. . 2013b. "Address by His Excellency the President Mahinda Rajapaksa at the Sixty First Session of the United Nations General Assembly.” September 24.

Ramos, Howard, James Ron, and Oskar N.T. Thoms. 2007. "Shaping the Northern Media's Human Rights Coverage, 1986-2000.” Journal of Peace Research 44(4): 385-406.

Response by H.E. Tamara Kunanayakam to media queries on the Amnesty International Report on the LLRC. September 10, 2011.

Reuters. 2015a. “Thailand says wraps up trafficking probe, rights groups sceptical.” 2015. June 23. 2015b. "Group of 32 countries criticizes Bahrain's human rights record." September 14.

Risse, Thomas, Stephen C. Ropp, Kathryn Sikkink. ed. The Power of Human Rights: International Norms and Domestic Change. New York: Cambridge University Press

Samaranayake, Nilanthi. 2011. Are Sri Lanka's Relations with China Deepening? An Analysis of Economic, Military, and Diplomatic Data, Asian Security 7(2): 119-146, DOI: 10.1080/14799855.2011.581603

Samarasinghe, Mahinda. 2011. Statement of Sri Lanka. UNHRC, 18 ${ }^{\text {th }}$ Regular Session. September 12. 2012a. Statement of Sri Lanka. High Level Segment. UNHRC, 19th Regular Session. February 27. 2012b. Statement of Sri Lanka. UNHRC, 19 th Regular Session. March 22. 2013. Statement of Sri Lanka. UNHRC, 22 ${ }^{\text {nd }}$ Regular Session. March 21.

"Satellite on reverse orbit." Sunday Times (Sri Lanka). July 27, 2014. 
Senewiratne, Kshenuka. 2011. Statement of Sri Lanka on the Statement of the High Commissioner for Human Rights Navanethem Pillay. UNHRC, 17th Regular Session. May 30.

Sengupta, Somini. 2008. "Take Aid From China and Take a Pass on Human Rights." The New York Times. March 9.

Simmons, Beth A. 2013. "From ratification to compliance: quantitative evidence on the spiral model." in The Persistent Power of Human Rights: From Commitment to Compliance, ed. Thomas Risse, Stephen C. Ropp, Kathryn Sikkink. New York: Cambridge University Press.

Smith-Cannoy, Heather. 2012. Insincere Commitments: Human Rights Treaties, Abusive States, and Citizen Activism. Washington D.C.: Georgetown University Press.

Sooka, Yasmin. “The empty findings of Sri Lanka's Military Court of Inquiry.” Groundviews. April 11, 2013.

Sri Lanka Army. 2011. Second National Victory Day Anniversary Celebrations Honour Invaluable Ranaviru Sacrifices. May 27.

Sri Lankan Army Media Unit. 2012. "Army Commander-Appointed Court of Inquiry Probing into LLRC Report Observations in Progress.” February 16.

2013. "LLRC Observations Cleared; Army Commander Hands Over Court of Inquiry Report to Secretary Defence." April 10.

Sri Lankan Ministry of Defence. 2011. Humanitarian Operation Factual Analysis July 2006 - May 2009, July.

Sri Lankan Ministry of External Affairs. 2010. "Statement on the Appointment of the Sri Lanka Panel of Experts by the Secretary General of the United Nations.” June 23. . 2011. "Minister of External Affairs Briefs Diplomatic Community on Darusman Report." April 28.

Sri Lanka Ministry of Finance. 2010. “2010 Pre-Election Budgetary Position Report,” March 1. available at http://www.treasury.gov.lk/docs/pressrelease/preElection-budgetary-2010.pdf

2013. "Estimate 2013: 4.2 Summary of Expenditure by Programme." available at http://www.treasury.gov.lk/web/guest/budget-estimates-2013.

Sri Lankan Ministry of Foreign Affairs. 2009. "GOSL Reaction on US State Department Report to the US Congress on Sri Lanka." October 22.

Sunday Times. 2015. "Rs. 400 m spent on foreign advisors for domestic HR inquiry.” February 15.

Thottam, Jyoti. 2009. “The Man Who Tamed the Tamil Tigers.” Time Magazine. July 13.

United Kingdom Foreign and Commonwealth Office. 2012. "Foreign Office Minister Responds to Report on the Conflict in Sri Lanka.” January 12.

United Nations Human Rights Council. 2009. “A/HRC/S-11/1: Assistance to Sri Lanka in the promotion and protection of human rights.” May 27.

United Nations Office of the High Commissioner for Human Rights. 2012. "Briefing Note on Sri Lanka / Human Rights Defenders." March 23.

United States Department of State. 2009. Report to Congress on Incidents During the Recent War in Sri Lanka. October 22. 2010. Report to Congress on Measures Taken by the Government of Sri Lanka and International Bodies to Investigate Incidents During the Recent Conflict in Sri Lanka and Evaluating the Effectiveness of Such Efforts. August 11.

2011. “Daily Press Briefing - December 19, 2011.” December 19.

United States Department of State, Bureau of Public Affairs. 2013. 2013 Investment Climate - Sri Lanka. April 19. 
United States Mission to the United Nations. 2010. "Statement by US Ambassador Susan E. Rice on Sri Lanka's Announcement of a Commission on Lessons Learned and Reconciliation.” May 10.

United States Representative to the Human Rights Council. 2012. "Statement by Ambassador Eileen Chamberlain Donahoe: U.S. Introduces HRC Resolution Promoting Reconciliation and Accountablity in Sri Lanka.” Human Rights Council, 19th Regular Session. March 22.

Vreeland, James. 2008. "Political institutions and human rights: Why dictatorships enter into the United Nations Convention Against Torture.” International Organization 62(1): 65-101.

Wijesinha, Rajiva. 2009. “Arbitrary Execution by Philip Alston.” Daily News. September 2. 